\title{
Willingness to Whistle Blow Among Muslim Consumers*
}

\author{
Mohani Abdul, Hashanah Ismail, Haslina Hashim, Mastura Mohd. Yusof \\ Universiti Putra Malaysia, Serdang Selangor, Malaysia
}

\begin{abstract}
The paper reports on a qualitative study using three focus groups drawn from Muslim consumers both local and foreign. Respondents were given vignettes depicting unethical halal claims scenarios to which respondents were required to respond. Two Malaysian consumer groups responded by declaring that they will whistle blow by reporting the matter to a religious authority, the Islamic Development Department (JAKIM), while another group that consists of six Muslim foreign students will just leave the business premise without making any complaints to any authority. The different course of actions taken could be explained by the diverse background of the Malaysian population and their level of awareness in selecting their halal food and their high degree of intolerance to such practice whilst the level of tolerance among foreign Muslim respondents might be different from their Malaysian counterparts or that they have never encountered such a problem before they came to Malaysia. The study also reports the response from JAKIM in relation to the relevant channels for whistle blowing regarding misleading halal labels.
\end{abstract}

Keywords: halal food, unethical practices, whistle blow

\section{Introduction}

To Muslims, every facet of his life is guided by Islamic rules of conduct and Islam as a way of life has set minimum quality standard for food that Muslims are permitted to consume. There is no compromise when comes to the question of halal food for Muslims as it is one of the tenets of Islam.

However, because much of the food we consume today are not produced directly by consumers themselves, Muslim consumers have to be guided by some form of labeling to indicate that the food or food ingredients they are about to purchase fall within what is permissible or halal by Islam. One such indicator is the presence of a halal logo attached to a product or visible on the premises of food eateries. Because consumers rely on such logos to give them the assurance that the food product is permissible for consumption, there has been anecdotal evidence in the local media that Muslim consumers are at risk of consuming non-halal food despite the food bearing the halal logo on its packaging, simply because the logo is false. False labeling puts Muslim consumers at risk because it means they are consuming prohibited or forbidden food, which is a sin in Islam. In the event that consumers come across such false labeling, what action would they take? It is the objective of this paper to examine Muslim consumers' response to incidences of false labeling or the discovery of passing off a non-halal

\footnotetext{
${ }^{*}$ The authors are grateful to Universiti Putra Malaysia for funding this research project under the "Research University Grant Scheme, Initiative 4”, funding scheme.

Mohani Abdul, Ph.D., associate professor, Faculty of Economics and Management, Universiti Putra Malaysia.

Hashanah Ismail, M.Sc, associate professor, Faculty of Economics and Management, Universiti Putra Malaysia.

Haslina Hashim, M.Sc, lecturer, Faculty of Economics and Management, Universiti Putra Malaysia.

Mastura Mohd. Yusof, graduate student, Graduate School of Management, Universiti Putra Malaysia.
} 
product as halal. Would Muslim consumers do nothing or go to the extreme of actually reporting such transgression to a higher authority, that is, to whistle blow? Whistle blowing is informing unethical or illegal practices. Therefore, strict enforcement regarding halal is part and parcel of the Islamic Development Department's (JAKIM) role in helping Muslims to fulfill the halal requirement in what they consume and use. According to Crook (2007), the situation can be improved by implementing a whistleblowers' policy. The rest of the paper is organized as follows: The next section discusses some empirical work on halal food labeling as well as literature on whistle blowing, followed by a description of the research method used in the study. The results and discussion thereon is then presented and the paper then concludes.

\section{Literature Review}

Modern day consumers do not directly involve themselves in the production of food, but are almost at the end of the food production chain, there is a need for assurance to Muslim consumers that along the way food has been prepared and sourced according to Islamic rules of "Halal". Assurance that food to be consumed is "Halal" is evidenced by the logo created by the religious authority in Malaysia and other countries whereby foods bearing such logos are deemed to be in compliance with Islamic food quality standard of wholesomeness. Nevertheless despite halal foods being stamped "Halal", there is anecdotal evidence that the food is not genuinely "halal". For example in June 2009, a local daily newspaper reported that a car dealer claimed that he bought a "Bak Kut Teh" that supposed to be halal (certified with a halal logo from Islamic Food Research Centre Asia) and yet despite being claimed as halal the product was discovered to have contained pork, an ingredient forbidden or haram to Muslims (Noor, 2009).

Previously, JAKIM officers could only accompany enforcement officers from the Domestic Trade and Consumerism Ministry to conduct raids on companies suspected to have misused the logo. However, the law will soon be amended to provide enforcement officers from the Islamic Development Department (JAKIM) powers to prevent the abuse of the halal logo by commercial enterprises (The Star, 2010). News of false labeling often come by way of tip offs and whistle blowing by concerned parties.

There is a dearth of information regarding the halal status on many of the products consumed or used by Muslims in Malaysia since labeling of all food as halal is not mandatory at this point in time. Therefore, it is only appropriate that Muslims are provided with the information that they need and one of the easiest way to provide the required information is through the details on the packaging. But that would not suffice as the cause of concern for Muslims is not only limited to products. For example, how are they to know the halal status of eateries owned by non-Muslims? The regulatory framework for halal foods and eateries in Malaysia come under several jurisdictions both civil and religious. The overall act relating to halal labeling is the Trade Description Act 1972-Trade Description Order (Use of Expression Halal, 1975) under the Ministry of Domestic Trade, Cooperatives and Consumerism (KPDNKK). The other regulations include the Food Act 1983 under the Health Ministry that covers cleanliness and safety of the contents and the Animal Importation Order 1962 under the Agriculture and Agro based Industries Ministry that requires the animals to be slaughtered according to Islamic ways. The multiplicity of regulatory authorities put consumers in a bind as they would not be able to select the right channel to voice complaints of false labeling. Therefore, consumer associations have long been clamoring for a law specifically for halal certification, and the actions that can be taken against false labeling, that compels producers and distributors to apply for the halal certification if they are to market their products to Muslims. The Prime Minister of Malaysia had stated that the government will draft the Halal Act to 
be enforced in year 2010 (Ariff, 2010). A potential valuable source of information to regulatory authorities on false halal labeling would be whistleblowers who can help authorities track down unscrupulous groups out to deceive unsuspecting Muslim consumers who remain at risk.

Whistle blowing can be defined as "the disclosure by a current or former organization member of illegal, inefficient, or unethical practices in an organization to persons or parties who have the power or resources to take action” (Miceli \& Near, 1988, p. 4). Drawing on the work of Graham (1986), Schultz Jr., Johnson, Morris, and Dyrnes (1993) proposed the variable of personal responsibility for reporting in their model of reporting questionable acts. When whistle blowing is perceived as pro social behavior in an organization, personal responsibility for reporting may influence an individual's decision making. Logically, individuals may feel obligated to report questionable acts by their moral sense of right and wrong (which is moral obligation or social responsibility) or sense of commitment and loyalty to the organization (role responsibility). In the case of false halal labeling, it is expected that the strength of personal responsibility to the community would motivate a consumer to report such unethical practice. Jones (1991) proposed the concept of moral intensity which consists of six components: magnitude of consequences, social consensus, and probability of effect, temporal immediacy, proximity, and concentration of effect. These six components represent the main characteristics of an ethical issue and they can vary considerably from issue to issue and underlies the drive to whistle blow.

\section{Methodology}

This study uses a qualitative approach as it allows for more flexibility and adaptability in the research (Carson, Gilmore, Parry, \& Gronhaug, 2001). An intensive rather than an extensive approach is considered more appropriate as it may offer more valuable insight into how people think and feel about a phenomenon and why this is so (De Ruyter \& Scholl, 1998). Since Halal food prerequisites are very much in the domain of religion, we interviewed a Muslim scholar as to the duty of a Muslim vis-à-vis whistle blowing. Next we interviewed three focus groups of Muslim consumers consisting of six members per group to seek their views on their willingness to whistle blow given an encounter with various scenarios of false labeling. We categorized the grouping as follows:

(1) The first group consists of equal number of three males and females academicians;

(2) The second group consists of equal number of three males and females non-academicians;

(3) The third group consists of six post graduate foreign students whereby two male participants from Iran and another two male participants from Nigeria. As for female participants, one is from Iran and another is from Zanzibar, Tanzania.

The focus groups are to enable researchers to determine how concerned Muslims are about halal labeling for food as well as eateries and their reactions when doubt persists. The qualitative nature of the research enabled respondents to report on their own subjective perceptions when they felt doubt and are therefore experiencing pressure to do something about it. This method enables the researchers to purposely select information rich respondents who would manifest the phenomenon of interest intensely (Patton, 1990). An interview was also held with a group of representatives from the Islamic Development Department of Malaysia or JAKIM, the agency entrusted with issuing halal certification on the certification process. 


\section{Results}

\section{Focus Groups}

There are two kinds of shop outlets: restaurant (eating outlets) and supermarkets that sell goods. According to respondents, they will inspect food products like canned food in the supermarkets to ensure that the products are halal certified. As for restaurants, the respondents used cues for indication of halal practices such as the sighting of halal logo clearly posted on the premises as well as visual evidence of who are the staff serving in the eateries and who goes into the restaurants (patrons). Some issues concerning restaurants and eating outlets discussed are as follows:

(1) Observation regarding staff: whether Muslim or otherwise. Most of our respondents agree that if the staffs are Malays, then the foods served are halal. If they doubt the religion of the staff or owner of the business premise, then they will look for evidence of the existence of a halal logo. In determining whether the logo is genuine or otherwise, most of them state that they will go for trust and their personal instinct based on the customers patronizing the restaurant. Again our respondents are of the opinion that if the customers are Malays, they assume that the foods served must be halal.

(2) Our respondents also highlighted that they are easily affected by what is reported in the media like rumors on the internet regarding halal/non halal eating outlets. If they encounter such rumors, they will try to avoid buying food from these outlets. This shows that the media like the internet plays an important role in disseminating news of unethical practices by food producers.

(3) When given seven sets of halal logos (one genuine and six fake halal logos) to group 1 and group 2 respondents to select the genuine one, none of the members from group 1 managed to select the right logo, as for group 2, four of the group members (two males and two females) managed to choose the right logo. Despite being from a highly knowledgeable group, very few could identify the correct halal logo. This could be attributed to the life styles between those who prefer to eat out and those who do not whereby the latter group can identify the correct logo better.

(4) All of group 1 and group 2 members would report to JAKIM if they encounter unethical practices or false labeling by food producers, and one of group 2 members would report to police besides JAKIM because she feels that she has been cheated by the food producer. On the other hand, all of group 3 members would leave the business premise without making any report. This could be due to their ignorance of the Malaysian Legal System or they have more tolerance towards such action or could be due to halal problem is not an issue in their home country. As explained by our foreign participants from Iran, Nigeria and Tanzania, halal issue is not a problem in their countries.

\section{JAKIM}

Based on our discussion with the JAKIM representatives, Ministry of Trade, Co-operatives and Consumerism of Malaysia has given the authority to the Islamic Development Department (JAKIM) to summon any agency that issued a forged halal certification to court in accordance to Trade Descriptions Act 1972. According to this Act, if a person commits an offence he or she can be charged up to RM250,000 or imprisonment for three years or both.

The concept of halal certification is not only confined to the ingredients but also on the procedures in accordance with the syarak. The main issue during the certification process is the cleanliness and hygiene of the process. The Malaysian Halal certification is among others, based on the standards for halal food covering 
Production, Preparation, Handling and Storage-General Guide Line (MS1500). According to JAKIM, the producers who have big producing plants and utilize machineries have no problem in obtaining such certificates. However, the ones who will face problems are the small scale entrepreneurs, for example, those who produce crackers. They may not have the GMP (Good Manufacturing Practice) and Hazard Analysis and Critical Control Points (HACCP) as they may have failed to meet the conditions on cleanliness.

JAKIM takes seriously each complaint and will act on it within 24 hours after the complaint is received and the e-mails will be replied within three working days after they have been forwarded to JAKIM's public relations department. JAKIM also provides the HALAL MALAYSIA status checking through SMS. The halal status of a product, premises or abattoir can be checked by typing the bar code number and sending a short message to 32728 .

Halal Malaysia Portal, which was launched in 2007, also serves as a one stop centre. The portal comes complete with the halal information column, the halal directory that serves as an avenue to lodge complaint and access to the Malaysian Halal Certificate application system. Under the Halal Directory, for example, the public can check the details on the halal certificate whether it is for products, eateries or abattoirs. The directory also provides the halal search facility based on bar code, product description or the name of the company that manufactured the product. It also has a list of foreign halal certificate issuing authorities.

\section{Discussion}

Most of our respondents are of the opinion that they will buy food from their trusted food producers that will sell or serve halal food besides looking for halal logo being displayed in their business premises. They also highlighted that they are easily affected by media like rumors on the internet regarding halal/non halal eating outlets. All of the Malaysian respondents will report to JAKIM if they encounter unethical food producers with false labeling, while the foreign Muslim respondents will just leave the business premise without making any report. This could explain the level of tolerance of our respondents towards such action or could be that the Malaysian Muslim respondents are more concerned with the attitude of food producers since Malaysia is a multiracial country, with various different religions practiced by its population, thus greater tendency there would be some food producers who falsely labelled their food products to attract Muslim consumers. As Islam is the national religion of Malaysia, the government plays a very important role in protecting the welfare of its Muslim population including its religious rules for halal food. JAKIM, being the sole agency in issuing halal certification, has the responsibility to disseminate the information and educate not only Muslim consumers on halal issues but also the Non-Muslim food producers.

\section{Recommendations}

Many of the respondents are of the impression that the main body which will take action against false labeling is JAKIM. Hence the Malaysian respondents almost unanimously state that they would not hesitate to inform JAKIM as the regulatory body. There is therefore an incorrect perception of the appropriate body to take action against false labeling because the Trade Description Act does not empower JAKIM to take action but action is within the jurisdiction of the Ministry of Domestic Trade. Because halal labeling is synonymous with Islamic matters most respondents associate the role of JAKIM to be that of the body empowered to take actions against those who transgress religious rulings. Currently, only officers from the Ministry can enforce the Trade Description Act. If consumers are to be more proactive in reporting false halal labeling, then it is essential that 
a policy be created which focuses on creating channels through which information should and could flow. The policy also should support and protect the whistleblowers' confidentiality or provide incentive to encourage the Muslims to whistle blow if they encounter such deceptive trade practices by the so called "halal food producers". Hence as a sole issuer of halal certification for producers and exporters, it is expected that JAKIM will have to play a major role in monitoring and auditing these halal food producers.

\section{References}

Ariff, M. M. (2010, February 9). Consumers need more info on halal issues. Bernama.

Carson, P., Gilmore, A., Parry, C., \& Gronhaug, K. (2001). Qualitative marketing research. London: Sage.

Crook, D. (2007). How to encourage whistleblowing, Journal of Financial Regulation and Compliance, 8(4), 326-332.

De Ruyter, K., \& Scholl, N. (1998). Positioning qualitative market research: Reflections from theory and practice. Qualitative Market Research: An International Journal, 1, 1-14.

Graham, J. (1986). Principled organizational dissent. In L. Cummings, \& B. Stows (Eds.), Research in organizational behavior. Greenwich, CT: JAI Press.

Jones, T. M. (1991). Ethical decision making by individuals in organizations: An issue-contingent model. Academy of Management Review, 16, 366-395.

Miceli, M., \& Near, J. (1988). Individual and situational correlates of whistle-blowing. Personnel Psychology, 41, $267-281$.

Noor, H. H. (2009, June 17). Khinzir logo halal, Guna logo dari Islamic food research centre Asia. Harian Metro.

Patton, M. Q. (1990). Qualitative evaluation and research methods. Sage. Newbury Park CA, USA.

Schultz, J. J .Jr., Johnson, D. A., Morris, D., \& Dyrnes, S. (1993). An investigation of the reporting of questionable acts in an international setting. Journal of Accounting Research, 31, 75-103.

The Star (2010, April 7). Empowering Jakim to prevent abuse of halal logo. Malaysian Newspaper. 